\title{
Anticancer potential of methanolic extracts from Pleurotus species on raji cells and antibacterial activity against Methicillin-Resistant Staphylococcus aureus
}

\author{
MUHAMMAD EVY PRASTIYANTO ${ }^{1, \bullet}$, RIZAL MAARIF RUKMANA ${ }^{2}$, DEWI KUNTHY SARASWATI ${ }^{1}$, \\ SRI DARMAWATI ${ }^{1}$, ENDANG TRI WAHYUNI MAHARANI ${ }^{3}$, YANUARITA TURSINAWATI ${ }^{4}$ \\ ${ }^{1}$ Department of Medical Laboratory Technology, Faculty of Nursing and Health Science, Universitas Muhammadiyah Semarang. Jl. Kedungmundu No. \\ 18, Semarang 50273, Central Java, Indonesia. Tel.: +62-24-76740288, "email: evy_prastiyanto@unimus.ac.id \\ 2Department of Medical Laboratory Technology, Faculty of Health Science, Universitas Setia Budi. Jl. Letjend Sutoyo, Surakarta 57127, Central Java, \\ Indonesia \\ ${ }^{3}$ Department of Chemistry Education, Faculty of Mathematics and Natural Sciences, Universitas Muhammadiyah Semarang. Jl. Kedungmundu No. 18, \\ Semarang 50273, Central Java, Indonesia \\ ${ }^{4}$ Department of Medicine, Faculty of Medicine, Universitas Muhammadiyah Semarang. Jl. Kedungmundu No. 18, Semarang 50273, Central Java, \\ Indonesia
}

Manuscript received: 15 October 2020. Revision accepted: 18 November 2020.

\begin{abstract}
Prastiyanto ME, Rukmana RM, Saraswati DK, Darmawati S, Maharani ETW, Tursinawati Y. 2020. Anticancer potential of methanolic extracts from Pleurotus species on raji cells and antibacterial activity against Methicillin-Resistant Staphylococcus aureus. Biodiversitas 21: 5644-5649. The aim of this work is to identify the potential effects of methanolic extracts from four species of the Pleurotus genus cultivated in Indonesia on nasopharynx cancer (Raji cell line), and to investigate their antibacterial activity against methicillin-resistant Staphylococcus aureus (MRSA). This study investigates four species members of Pleurotus (Pleurotus ostreatus, $P$. cystidiosus, P. flabellatus, and P. pulmonarius var. stechangii). Dry Samples were extracted with methanol to yield crude extracts. Cytotoxicity screening was conducted using MTT assay of dry extracts, while antibacterial activity was calculated based on the minimum inhibitory concentration (MIC) and minimum bactericidal concentration (MBC) using Mueller-Hinton broth, via the microdilution method. Compounds were analyzed using thin-layer chromatography (TLC). P. flabellatus provided the highest yield of dry extract $(20.8 \%)$ with the lowest value of $\mathrm{IC}_{50}(556.226 \mu \mathrm{g} / \mathrm{mL})$ compared to the three other species investigated. Antibacterial activity was calculated as MIC and MBC values against MRSA by the P. flabellatus extract which reached $6.25 \mathrm{mg} / \mathrm{mL}$ and 250 $\mathrm{mg} / \mathrm{mL}$, respectively. The result of TLC of the dry extract of $P$. flabellatus revealed the presence of terpenoids. $P$. flabellatus has the potential to be developed as both an anti-cancer and an antibacterial agent, especially against Raji cells and MRSA strains. However, further in vivo research and discovery of the modes of action involved are still needed to shed light on these effects. Studies can provide new information about the benefits of Pleurotus as a source of natural anticancer and antibacterial compound.
\end{abstract}

Keywords: Antibacterial activity, anticancer, MRSA, mushrooms, Pleurotus

\section{INTRODUCTION}

Species of oyster mushroom widely cultivated in Indonesia are Pleurotus ostreatus, P. cystidiosus, $P$. flabellatus, and P. pulmonarius var. stechangii. Oyster mushroom has nutritional importance due to its amino acids, vitamins, saturated and unsaturated fatty acids, macro and microelements, crude fibers, and low energy (Owaid et al. 2015). Oyster mushrooms can be safely eaten (Majeed et al. 2017) and are used as a form of medication. Specifically, oyster mushrooms can be used as antimicrobial (Owaid et al. 2015), antifungal (Owaid et al. 2016), and anticancer (Cha et al. 2018). Research has shown that extraction from $P$. ostreatus using water as the solvent will result in the most significant cytotoxicity toward the prostate cancer cell line, PC-3 (Gu and Sivam 206AD). According to (Prastiyanto et al. 2016) extract of P. ostreatus exhibits antimicrobial effects on Enterobacter aerogenes, Staphylococcus aureus, and Candida albicans.
Nasopharynx cancer (NPC) is a kind of malignant tumor that occurs in the head and neck, arising from the epithelial tissue covering the nasal cavity. This type of cancer cell is located in the fossa of Rosenmüller situated in the back of the Eustachian tube of the nasopharynx (Pelealu et al. 2015). The global incidence rate of NPC is relatively low, at less than $1 / 100,000$ of population per year. However, in several particular locations, such as South China and Southeast Asian countries there is a midlevel to high incidence rate of NPC. The etiological factor for NPC arises from the Epstein-Bar virus (EBV) infection. It is found that patients with NPC will have higher EBV load than the normal population (Pelealu et al. 2015). Raji cells come from a continuous cell line derived from Blymphocytes of a Burkitt's lymphoma patient infected by EBV, and they have some cell damage on the down-stream caspase-3 (Kawabata et al. 2017).

In addition to cancer, infection by methicillin-resistant S. aureus (MRSA) is one of the most dangerous diseases. Infections caused by MRSA bacteria consume more health 
care resources than are consumed by patients infected with non-resistant strains of the same bacteria (Word Health Organization 2018). In consequence, novel antibacterial agents are needed from natural biological sources (Asagabaldan et al. 2019; Lestari et al. 2019; Prastiyanto et al. 2020b; 2020a, 2020c). Neutral proteoglycans derived from the $P$. ostreatus mycelia have been reported that could be used as immunomodulators and anticancer agents (Sarangi et al. 2006). 3-(2-aminopheny1thio)-3-hydroxypropanoic acid from P.ostreatus potential as antimicrobial agent (Younis et al. 2015). There is no information about another species from genus Pleurotus as anticancer and antibacterial agent. Based on that, the aim of this research is to identify the potential effects of methanolic extracts from four species of the Pleurotus genus cultivated in Indonesia on nasopharynx cancer (Raji cell line), and to investigate their antibacterial activity against MRSA. These studies are expected to provide new information about the benefits of Pleurotus. In addition, it also can support the Pleurotus as a source of natural anticancer and antibacterial. The research aims were to identify the potential effects of methanolic extracts from four species of the Pleurotus genus cultivated in Indonesia on nasopharynx cancer (Raji cell line), and to investigate their antibacterial activity against MRSA.

\section{MATERIALS AND METHODS}

\section{Collection of samples}

The Pleurotus species used in this study (Pleurotus ostreatus, $P$. cystidiosus, $P$. flabellatus, and $P$. pulmonarius var. stechangii) were obtained from the Asosiasi Petani Jamur Indonesia (APJI), located at Rembang, Central Java, Indonesia. All the samples were collected in February 2019. The fresh fruiting bodies were washed with water to remove all unwanted materials and then rinsed with sterilized distilled water, then dried in an oven at $40{ }^{\circ} \mathrm{C}$. The dried Pleurotus were then milled into fine powder using a milling machine and stored in a sterile air-tight container until further use.

\section{Cell lines and MRSA}

Raji cells (ATCC@CCL-86 $6^{\mathrm{TM}}$ ) were obtained from the Laboratory of Parasitology, Faculty of Medicine, Universitas Gadjah Mada, Yogyakarta, Indonesia. MRSA was collected from the dr. Kariadi Hospital, Semarang, Indonesia. Isolates were identified and susceptibility patterns were obtained using Vitek ${ }^{\circledR} \mathrm{MS}$.

\section{Research sample extraction}

Extracts of Pleurotus fruiting bodies were prepared by maceration with methanol. $100 \mathrm{~g}$ of powdered Pleurotus fruiting body was soaked in $300 \mathrm{~mL}$ of solvent for 24 hours at room temperature, protected from light, and shaking. Solvent replacement was carried out daily until the solution was clear, with the assumption that there was no further active compound contained in the dry powder. The resulting extracts were centrifuged at $3000 \mathrm{r} / \mathrm{min}$ for five minutes at $4^{\circ} \mathrm{C}$. The supernatant was filtered through
Whatman filter paper No. 1. The maceration solutions were concentrated under reduced pressure using a rotary evaporator at $50{ }^{\circ} \mathrm{C}$. The crude extracts were collected and allowed to dry at room temperature.

\section{Tests of the toxicity of extracts on the Raji cancer cell line}

The procedures for toxicity testing of the extracts were as follows:

\section{Raji cell propagation}

One milliliter $(1 \mathrm{~mL})$ of cell-line stock from cryogenic storage was taken, melted and then put into a conical 15 $\mathrm{mL}$ tube and $10 \mathrm{~mL}$ Iscove's Modified Dulbecco's Medium (IMDM) media was added. The cell culture contained the following materials: fetal bovine serum (FBS) $10 \% \mathrm{v} / \mathrm{v}$ (Gibco) and penicillin-streptomycin $2 \% \mathrm{v} / \mathrm{v}$ (Sigma) in an IMDM media $\left(\mathrm{Gibco}^{\circledR}\right)$. This mixture was then centrifuged at $3000 \mathrm{rpm}$ for five minutes. The supernatant was then removed and applied to a pellet using fingers. The pellet produced was added to $10 \%$ FBS as the growing medium and this slowly became homogenous. This was then put into a new culture flask and placed in a $5 \% \mathrm{CO}_{2}$ incubator at $37^{\circ} \mathrm{C}$. After 24 hours, the medium was substituted and the cells continued to be developed until $80 \%$ coverage of the surface was achieved. The cells were then ready to be used.

\section{Cytotoxic activities of Pleurotus sp. methanolic extracts (MTT Assay}

Then a cell suspension containing $1 \times 10^{4}$ cell/100 $\mu \mathrm{L}$ of culture media was created and $50 \mu \mathrm{L}$ of cell suspension was put into each well of a 96-well microwell plate, except for the three wells in the bottom right-hand corner. The plate was continually incubated for 24 hours. A $10 \mathrm{mg}$ extract dissolved in $100 \mu \mathrm{L}$ dimethyl sulfoxide (DMSO) was placed in an Eppendorf tube and vortexed to create sample stock solution with concentration of $1 \times 10^{5} \mu \mathrm{g} / \mathrm{mL}$. Test solution with dilution was put through a laminar airflow cabinet (Labconco Purifier Class II Biosafety Cabinet) to keep it aseptically for every test. Cell culture that had been incubated was treated by methanol extraction, by adding $100 \mu \mathrm{L}$ of test solution of various dosages, 125 , $250,500,750,1000,2000$, and $3000 \mu \mathrm{g} / \mathrm{mL}$, to each microwell, except for the cell and media control wells. This treatment was carried out in three cycles. Cell culture with the addition of test solution was placed into the incubator for 24 hours. After incubation, the solution was added by MTT (1 mL MTT into IMDM media and $10 \mathrm{~mL}$ culture media, to achieve concentration of $0.5 \mathrm{mg} / \mathrm{mL}$ ) to the microwells and incubated again for four hours. Cultured cells were then inoculated with $100 \mu \mathrm{L}$ of $10 \%$ sodium dodecyl sulfate stopper with $\mathrm{HCl} 0.1 \mathrm{M}$ to dissolve formazan purple crystal, and were put into a shaker for five minutes. This was then left at room temperature overnight. The level of absorbance was read by a microplate ELISA reader at $\lambda 595 \mathrm{~nm}$. The absorbance results were then analyzed to identify the percentage of cell viability, using the following formula (Nurhayati et al. 2015):

$\%$ cellviability $=\frac{(\text { sampleabsorbance }- \text { mediumabsorbance control })}{(\text { cellcontroleabsorbance }- \text { mediumabsorbancecontrol })} \times 100$ 
Determining $I C_{50}$ of potential of species extractions

The various dosages of treatment $(125,250,500,750$, 1000, 2000, and $3000 \mu \mathrm{g} / \mathrm{mL}$ ) are represented as $\mathrm{X}$, whereas Raji cell viability is represented by $Y$. Determining $\mathrm{IC}_{50}$ for each extraction using multiple regression analysis $(\mathrm{Y}=\mathrm{b} 1 \mathrm{X}+\mathrm{b} 0)$ was carried out by use of a trendline chart in Microsoft Excel. The concentration of inhibitors of $50 \%$ of cells was then evaluated by adding 50 to variable $\mathrm{Y}$ to determine variable $\mathrm{X}$, based on the line equation $\mathrm{Y}=\mathrm{b} 1 \mathrm{X}+\mathrm{b} 0$. The value of the lowest extraction $\mathrm{IC}_{50}$ indicates that this extraction is a potential of methanolic extraction.

\section{Anti-MRSA assay}

The procedure for anti-MRSA assay of extractions is as follows:

\section{Bacterial preparation}

MRSA was subcultured 24 hours at $35 \pm 2^{\circ} \mathrm{C}$ on $5 \%$ sheep blood agar (BAP). The bacterial colonies were homogenized and adjusted to 0.5 McFarland standards $\left(5 \times 10^{8} \mathrm{CFU} / \mathrm{mL}\right)$ using spectrophotometry.

\section{Minimum inhibitory concentrations (MIC) and minimum bactericidal concentration $(M B C)$}

The MIC of the extracts was determined using MuellerHinton broth microdilution (CLSI 2019). MIC determination was performed by serial dilution technique using 96-well microwell plates. Extract amounts of $100 \mu \mathrm{L}$ were placed into each well. Then, $100 \mu \mathrm{L}$ of bacterial cell suspension (0.5 McFarland) was added to each. Each test was done in triplicate. The Pleurotus extracts were serially diluted to produce final concentrations of $0.49 \mathrm{mg} / \mathrm{mL}$ to $1000 \mathrm{mg} / \mathrm{mL}$. The microwell plates were then incubated for 24 hours at $35 \pm 2{ }^{\circ} \mathrm{C}$. Dimethyl sulfoxide was used as a control and Mueller-Hinton broth as negative control. Tetracycline and vancomycin were used as positive. The MIC was determined as the lowest concentration of extract that completely inhibited the growth of the MRSA detected by the unaided eye (Valle et al. 2015). MBC was defined as the concentration which exhibits zero growth of the colonies compared to the culture of the initial inoculum of the same strain (Manilal et al. 2020; Prastiyanto et al. 2020b). The Wells were subcultured using a $10 \mu \mathrm{L}$ inoculating loop on to a BAP at $(35 \pm 2)^{\circ} \mathrm{C}$ for $16-20 \mathrm{~h}$ incubation.

\section{Thin-layer chromatography of potential extraction}

The bioactive content of the methanolic extractions was monitored using TLC. Stationary phase of silica gel 60 F254 by mobile phase to terpenoid compound such as Hexane: ethyl acetate $=93: 7$, Alkaloid compound using Toluene: ethyl acetate: diethylamine $=7: 2: 1$, while Phenolic compound using Ethyl acetate: formic acid: toluene: water $=6: 1.5: 3: 0.5$. TLC activation was conducted by applying a hairdryer for ten minutes. The extraction was then maculated by microhematocrit to the lower TLC plate with 2-3 $\mathrm{mm}$ macular diameter and maculation range of 1 $\mathrm{cm}$, and was then dried. The maculated TLC plate was put into a growing vessel, until increased up to $0.5 \mathrm{~cm}$ from limitation to maximum capacity, and was then dried. The chromatogram profile was visualized using UV rays (UV $\lambda$ $=254 \mathrm{~nm}$ and $366 \mathrm{~nm}$ ) and then sprayed with anisaldehyde-sulfuric acid, Dragendorff's reagent, and $\mathrm{FeCl}_{3}$ then put into an oven at $100^{\circ} \mathrm{C}$ for one minute.

\section{RESULTS AND DISCUSSION}

\section{Pleurotus species extraction}

Extraction is a process that aims to take active compounds from within cell bodies by dissolving active compounds that can then be extracted. The nature of extracted compounds will be determined by the type of solution applied (Tiwari et al. 2011). The results of extractions of Pleurotus using methanol are illustrated in Table 1 . The highest yield $20.8 \%$ is from the methanolic extraction of the pink oyster mushroom (P. flabellatus), with the physical characteristic of a blackish paste. This indicates that $P$. flabellatus has more of the active compound than the other three species of Pleurotus.

The present study has shown that $P$. flabellatus has more active compounds than the three other species of Pleurotus. The quantity of secondary metabolites is affected by both external. Several external factors affect processes, such as pathogen induction, moisture, salinity, and temperature. These external factors were controlled (by taking samples from homogenous environments, such as from APJI. The large yield $(20.8 \%)$ was affected by the ability of $P$. flabellatus fruiting bodies to synthesize secondary metabolites.

Table 1. Methanolic extract of four species of Pleurotus

\begin{tabular}{lcccc}
\hline \multirow{2}{*}{ Species of Pleurotus } & \multicolumn{2}{c}{ Weight } & \multirow{2}{*}{ Yield (\%) } & \multirow{2}{*}{ Physical characteristics of extract } \\
\cline { 2 - 3 } & Powder (grams) & Extract (grams) & & Brown paste \\
\hline P. ostreatus & 19.8 & 2.1 & 10.6 & Blackish paste \\
P. flabellatus & 12.5 & 2.6 & 20.8 & Brown paste \\
P. cystidiosus & 14.2 & 1.6 & 11.3 & Brown paste \\
P. pulmonarius var. stechangii & 22.9 & 1.1 & 4.8 & \\
\hline
\end{tabular}






Figure 1. MIC value of $P$. flabellatus against MRSA at $62.5 \mathrm{mg} / \mathrm{mL}$.
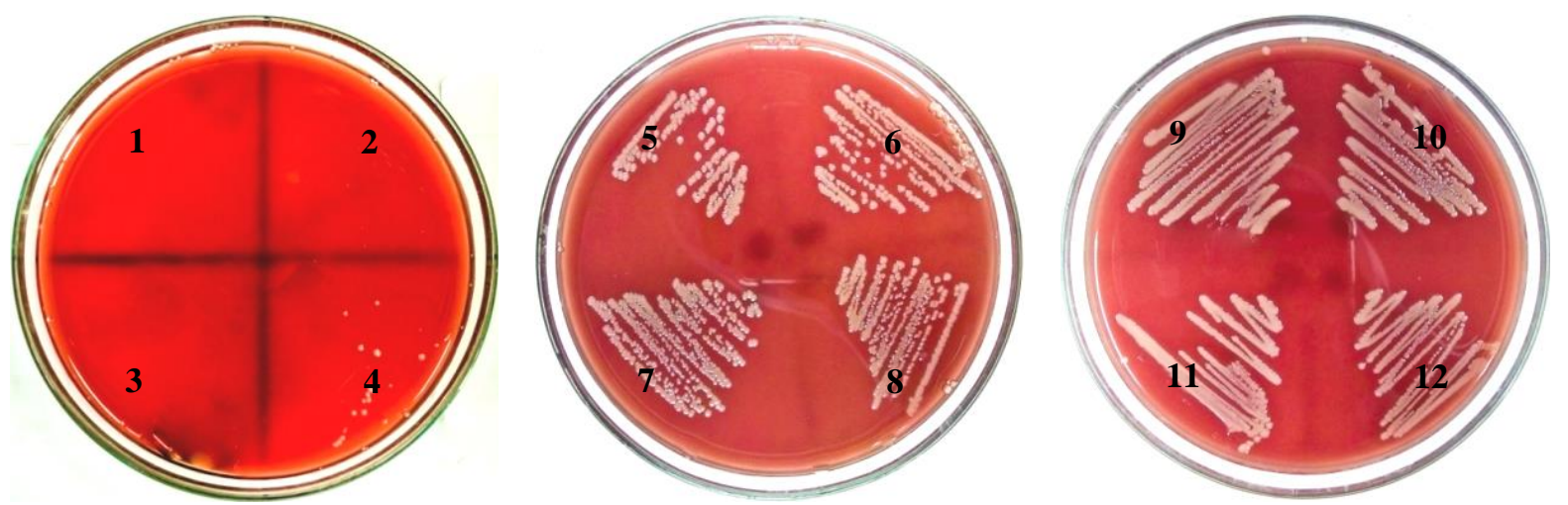

Figure 2. MBC value of P. flabellatus against MRSA: $1.1000 \mathrm{mg} / \mathrm{mL}, 2.500 \mathrm{mg} / \mathrm{mL}, 3.250 \mathrm{mg} / \mathrm{mL}, 4.125 \mathrm{mg} / \mathrm{mL}, 5.62 .5 \mathrm{mg} / \mathrm{mL}, 6$. $31.2 \mathrm{mg} / \mathrm{mL}, 7.15 .6 \mathrm{mg} / \mathrm{mL}, 8.7 .81 \mathrm{mg} / \mathrm{mL}, 9.3 .91 \mathrm{mg} / \mathrm{mL}, 10.1 .95 \mathrm{mg} / \mathrm{mL}, 11.0 .98 \mathrm{mg} / \mathrm{mL}, 12.0 .49 \mathrm{mg} / \mathrm{mL}$

\section{Cytotoxicity testing of extractions}

The cytotoxicity test results using MTT assay were measured with $\mathrm{IC}_{50}$ scores as presented in Table 2 . The lowest $\mathrm{IC}_{50}$ score $(556.226 \mu \mathrm{g} / \mathrm{mL})$ is in P. flabellatus, and this indicates that the methanol extraction of $P$. flabellatus is potentially more cytotoxic towards Raji cells than extractions of the three other oyster mushroom species.

The current results show that methanolic extracts of $P$. ostreatus, $P$. flabellatus, and $P$. cystidiosus have $\mathrm{IC}_{50}$ values of less than $1000 \mu \mathrm{g} / \mathrm{ml}$ on Raji cells. The present study has also demonstrated that methanolic extracts of $P$. flabellatus have high levels of cytotoxic action on Raji cells. Previous studies have shown that extracts of natural ingredients have cytotoxic activity against cancer cells. The ethanolic extracts of rice bran of the Woja Laka cultivar of black rice have cytotoxic activity on HepG2 cells and Raji cells, with IC50 values of $857.23 \pm 99.19$ and $816.61 \pm$ 85.31, respectively (Rukmana et al. 2016). Previous studies of the active fraction of Woja Laka black rice bran by (Rukmana and Soesilo 2017) have shown that it can inhibit proliferation, induce apoptosis, and arrest the G0/G1 phase of the cell cycle in HepG2 cells.

\section{Anti-MRSA activity}

The anti-MRSA activity of the $P$. flabellatus extracts was assayed in vitro by the agar microdilution method against MRSA. P. flabellatus exhibited the smallest value of MIC against MRSA (62.5 mg/mL) (Figures 1). The MBC was defined as the lowest concentration of the $P$. flabellatus extract that did not growth of MRSA. The present study showed that $250 \mathrm{mg} / \mathrm{mL}$ extract did not grow MRSA (Figure 2). This suggests that $P$. flabellatus has the potential to be developed as an antibacterial agent for MRSA strains.
Pleurotus flabellatus has anti-MRSA potential. The present study has demonstrated that methanolic extract of $P$. flabellatus exhibited the smallest value of MIC and MBC against MRSA $(62.5 \mathrm{mg} / \mathrm{mL}$ and $250 \mathrm{mg} / \mathrm{mL})$. The bioactive content of methanolic extract was identified using TLC and the results show that it belongs to the terpenoid compound group. The mechanism of anti-MRSA activity of the terpenoid compound from the TLC results is still unknown, but according to (Ferraz et al. 2018), Terpenoids have lipophilic character, terpenoids can easily interact with the bacterial wall, interfering with the biosynthesis of its components. Furthermore, these compounds penetrate the bacterial cell and may also interfere with protein synthesis and DNA replication.
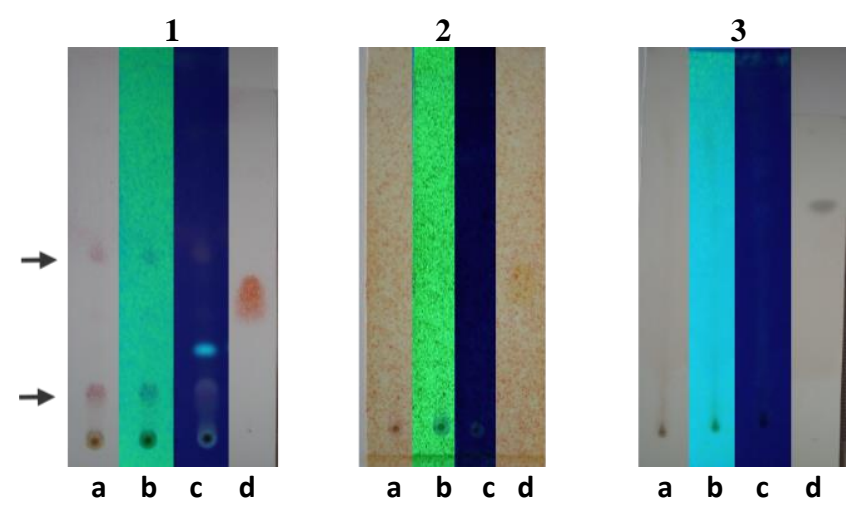

Figure 3. Results of TLC spraying with 1 . Anisaldehyde-sulfuric acid; 2. Dragendorff's reagent, 3. $\mathrm{FeCl}_{3}$ : a. Visible light, b. UV 254 , c. UV 366, d. Comparator (thymol $10 \mathrm{mg} / 1 \mathrm{~mL}$ ethanol) (quinine $10 \mathrm{mg} / 1 \mathrm{~mL}$ ethanol) galactic acid $10 \mathrm{mg} / 1 \mathrm{~mL}$ ethanol in visible light. The arrows indicate positive spots 
Table 2. Cytotoxicity test of extractions on Raji cells using MTT assay

\begin{tabular}{lccc}
\hline Species of Pleurotus & Solvent & Linear regression equation & IC $_{\mathbf{5 0}}(\boldsymbol{\mu g} / \mathbf{m L})$ \\
\hline P. ostreatus & Methanol & $\mathrm{Y}=-0.0408 \mathrm{X}+80.855$ & 756.250 \\
$P$. flabellatus & Methanol & $\mathrm{Y}=-0.1044 \mathrm{X}+108.07$ & 556.226 \\
P. cystidiosus & Methanol & $\mathrm{Y}=-0.1336 \mathrm{X}+143.71$ & 701.422 \\
$P$. pulmonarius var. stechangii & Methanol & $\mathrm{Y}=-0.0631 \mathrm{X}+123.43$ & 1163.70 \\
\hline
\end{tabular}

Table 3. Positive tests of sprays on TLC spot results

\begin{tabular}{lllcc}
\hline Compound group & \multicolumn{1}{c}{ Solvent system } & \multicolumn{1}{c}{ Spray reagent } & Color test & Result \\
\hline Terpenoid & n-hexane: ethyl acetate 93:7 & Anisaldehyde-sulfuric acid & Orange spot & + \\
Alkaloid & Toluene:ethyl acetate: diethylamine 7:2:1 & Dragendorff's reagent & Orange spot & - \\
Phenolic & Ethyl acetate: formic acid: toluene: water 6:1.5:3:0.5 & $\mathrm{FeCl}_{3}$ & Dark spot & - \\
\hline
\end{tabular}

\section{The bioactive content of the methanolic extractions}

The bioactive content of the methanol extractions was identified by using TLC with a silent phase such as silica gel 60 F254 then testing with spray to classify the group it belonged to. Figure 2 and Table 3. Based on the reactions of the dyeing reagent, it is shown that the TLC results belong to the terpenoid group of compounds. This result is in line with previous research carried out by (Jayakumar et al. 2011) indicating that oyster mushrooms can produce secondary metabolites such as terpenoids as their most rich and varying secondary metabolite compound.

Inhibition of terpenoid component in TLC results is still unknown. The terpenoids can hinder cancer cell growth and induce apoptosis. Sesquiterpene improves the protein production that supports apoptosis processes, such as caspase-3, caspase-8, Bax, p53, and Fas. Monoterpene decreases 3-hydroxymethyl glutaryl coenzyme A reductase. Diterpene stops the cancer cell cycle in the G2 phase, blocks cdk-1, and improves p53, caspase-3, and caspase- 9 (Thoppil and Bishayee 2011). The P. flabellatus were shown to be potentially developed as anticancer and antibacterial agents, especially for Raji cell line and MRSA. Further in vivo research and discovery of action modes are needed to shed light on their anticancer and antibacterial effects. Study can provide new information about the benefits of Pleurotus as a source of natural anticancer and antibacterial against.

In conclusion, $P$. flabellatus has the potential to be developed as both an anti-cancer and an antibacterial agent, especially against Raji cells and MRSA strains. However, further in vivo research and discovery of the modes of action involved are still needed to shed light on these effects.

\section{ACKNOWLEDGMENTS}

The authors thank the Association of Indonesian Mushroom Farmers (Asosiasi Petani Jamur Indonesia, APJI), Rembang, Central Java, Indonesia.

\section{REFERENCES}

Asagabaldan MA, Bedoux G, Bourgougnon N. 2019. Bacterial isolates from bryozoan Pleurocodonellina sp.: Diversity and antimicrobial potential against pathogenic bacteria. Biodiversitas 20: 2528-2535. DOI: 10.13057/biodiv/d200914

Cha YJ, Alam N, Lee JS, Lee KR, Shim MJ, Lee W, Kim HY, Shin PG, Cheong JC, Bok Y, Lee TS, Jeong Y, Alam N, Lee JS, Lee KR, Shim MJ, Cha YJ, Alam N, Lee JS, Lee KR, Shim MJ, Lee MW, Kim HY, Shin PG, Cheong JC, Yoo YB, Lee TS. 2018. Anticancer and immunopotentiating activities of crude polysaccharides from Pleurotus nebrodensis on Mouse Sarcoma 180. Mycobiology 40: 236-243. DOI: 10.5941/MYCO.2012.40.4.236.

CLSI. 2019. M100 Performance Standards for Antimicrobial Susceptibility Testing, 29th ed. J Serv Marketing. DOI: 10.1108/08876049410065598

Ferraz AA, Pontes MC, Bastos N, Paula A, Oliveira D, Picot L, Ara L, Guedes R. 2018. Antibacterial activity of terpenoids isolated from Cnidoscolus quercifolius Pohl (Euphorbiaceae), a Brazilian medicinal plant from Caatinga biome. Eur J Integr Med 24: 30-34. DOI: 10.1016/j.eujim.2018.10.011.

Gu Y, Sivam G. 2006. Cytotoxic effect of oyster mushroom Pleurotus ostreatus on human androgen-independent prostate cancer PC-3 cells. J Med Food 9: 196-204. DOI: 10.1089/jmf.2006.9.196.

Jayakumar T, Thomas PA, Sheu JR, Geraldine P. 2011. In-vitro and invivo antioxidant effects of the oyster mushroom Pleurotus ostreatus. Food Res Intl 44: 851-861.

Kawabata BY, Hirokawa M, Kitabayashi A, Horiuchi T, Kuroki J. 2017. Defective apoptotic signal transduction pathway downstream of Caspase-3 in Human B-Lymphoma cells: A novel mechanism of nuclear apoptosis resistance. Blood J Am Soc Hematol 94 (10): 35233530 .

Lestari SD, Sadiq ALO, Safitri WA, Dewi SS, Prastiyanto ME. 2019. The antibacterial activities of bacteriocin Pediococcus acidilactici of breast milk isolate against methicillin-resistant Staphylococcus aureus. J Phys Conf Ser 1375: 012021. DOI: 10.1088/17426596/1374/1/012021.

Majeed M, Khan MU, Owaid MN, Khan MR, Shariati MA, Igor P, Ntsefong GN. 2017. Development of oyster mushroom powder and its effects on physicochemical and rheological properties of Bakery products. J Microbiol Biotechnol Food Sci 6: 1221-1227. DOI: 10.15414/jmbfs.2017.6.5.1221-1227.

Manilal A, Raghavanpillai K, Shewangizaw M, Aklilu A, Seid M, Merdekios B, Tsegaye B. 2020. In vitro antibacterial activity of medicinal plants against biofilm-forming methicillin-resistant Staphylococcus aureus: efficacy of Moringa stenopetala and Rosmarinus officinalis extracts. Heliyon 6 (1): e03303. DOI: 10.1016/j.heliyon.2020.e03303.

Nurhayati A, Pratiwi R, Wahyuono S, Istriyati, Abdillah S. 2015. Original research article cellular mechanism of anti-cancerous activity in 
active marine sponge Cinachyrella anomala against T47D cell 4. Int J Curr Microbiol App Sci 4 (3): 785-791.

Owaid MN, Abed AM, Nassar BM. 2015a. Recycling cardboard wastes to produce blue oyster mushroom Pleurotus ostreatus in Iraq. Emirates J Food Agric 27: 537-541. DOI: 10.9755/ejfa.2015.04.118.

Owaid MN, Abed AM, Nassar BM, Al-etawi. 2015b. Effect of cellulosic matter and container size on cultivation and yield of oyster mushroom Pleurotus ostreatus. J Med Herbs Ethnomed (1): 59-63. DOI: $10.5455 /$ jmhe.

Owaid MN, Salahuddin S, Al S, Abed IA, Shahbazi P, Sabaratnam V. 2016. Antifungal activities of some Pleurotus species (higher basidiomycetes). Walaikak J 14: 215-224.

Pelealu O, Palandeng O, Adithia I, Rahardjo S. 2015. Nasopharyngeal Carcinoma at Otolaryngology Department Prof. RD Kandou Hospital Manado. Am J Med Sci Med 3: 1-3. DOI: 10.12691/ajmsm-3-1-1

Prastiyanto M, Darmawati S, Setyaningtyas A, Trisnawati L, Syafira A 2016. Antimicrobial activity and identification of the compounds of methanol extract from the Pleurotus ostreatus fruiting body. ElHayah 6 (1): 29-34.

Prastiyanto ME, Azizah IH, Haqi HD, Yulianto BD, Agmala AB Radipasari ZD, Astuti NAD. 2020a. In-vitro antibacterial activity of the seed extract of three members Artocarpus towards methicillinresistant Staphylococcus aureus (MRSA). J Teknologi Laboratorium 9: 1-6. DOI: 10.29238/teknolabjournal.v9i2.237.

Prastiyanto ME, Tama PD, Ananda N, Wilson W, Mukaromah AH 2020b. Antibacterial potential of Jatropha sp. latex against multidrugresistant bacteria. Intl J Microbiol 2020. DOI: 10.1155/2020/8509650.
Prastiyanto ME, Wardoyo FA, Wilson W, Darmawati S. 2020c. Antibacterial activity of various extracts of Averrhoa bilimbi against multidrug-resistant bacteria. Biosaintifika 12: 163-168.

Rukmana RM, Soesilo NP. 2017. Chemopreventive activities of 'Woja Laka' black rice bran fractions on liver carcinoma HepG2 cells. Biomed J 10: 1677-1684.

Rukmana RM, Soesilo NP, Pratiwi R. 2016. The effect of ethanolic extract of black and white rice bran (Oryza sativa $\mathrm{L}$.) on cancer cells. Indones J Biotechnol 21: 63-69.

Sarangi I, Ghosh D, Bhutia SK, Mallick SK, Maiti TK. 2006. Anti-tumor and immunomodulating effects of Pleurotus ostreatus mycelia-derived proteoglycans. Intl Immunopharmacol 6: 1287-1297. DOI: 10.1016/j.intimp.2006.04.002.

Thoppil RJ, Bishayee A. 2011. Terpenoids as potential chemopreventive and therapeutic agents in liver cancer. World J Hepatol 3 (9): 228. DOI: $10.4254 /$ wjh.v3.i9.228.

Tiwari P, Kumar B, Kaur M, Kaur G, Kaur H. 2011. Phytochemical screening and extraction: A review. Intl Pharm Sci 1: 98-106.

Valle Jr DL, Andrade JI, Puzon JJ, Cabrera EC, Rivera WL. 2015. Antibacterial activities of ethanol extracts of Philippine medicinal plants against multidrug-resistant bacteria. Asian Pac J Trop Biomed 5 (7): $532-40$.

Word Health Organization. 2018. Resistance in bacteria Antibiotic. http://www.who.int/mediacentre/factsheets/fs194/en/ [4 Sep 2018].

Younis AH, Wu F-S, El Shikh H. 2015. Antimicrobial activity of extracts of the oyster culinary medicinal mushroom Pleurotus ostreatus (Higher Basidiomycetes) and identification of a new antimicrobial compound. Intl J Med Mushrooms 17: 579-590. DOI: 10.1615/IntJMedMushrooms.v17.i6.80. 